\title{
Short-Run and Long-Run Inflation and Economic Growth Nexus in Ghana
}

\author{
Ferdinand Ahiakpor \\ Post - doctoral Research Fellow, Department of Economic and Econometrics, University of \\ Johannesburg, South Africa; Email: fahiakpor@yahoo.com or fahiakpor@ucc.edu.gh \\ and
}

Isidore Adagwine Akapare

Department of Economics, University of Cape Coast, Cape Coast, Ghana

DOI: http://dx.doi.org/10.4314/gjds.v11i2.3

\begin{abstract}
This paper examines the relationship between inflation and economic growth in Ghana. Using quarterly data from 1986Q1 to 2012Q4. The study employs Co-integration and error correction model. The study reveals that capital, government expenditure, labour force and money supply have a positive impact on GDP. In addition, inflation and interest rate has a decreasing impact on economic growth. The study recommends inflation targeting as best monetary policy. There is the need for government to increase expenditure in the area of infrastructure development and human capital to increase output.
\end{abstract}

Keywords: Co - Integration, Inflation, ECM Model, Economic Growth, Ghana

\section{Introduction}

According to Barro (2013), most businesses and households perform poorly when inflation is high and unpredictable. Empirical findings on the link between inflation and economic growth has been mixed. According to Khan and Eggoh (2014), the mixed result mostly found is due to lack of consensus in the fact that the inflation-growth relationship depends upon country-specific characteristics. However, the academic literature contains a lot of theoretical work on the costs of inflation, as reviewed by Briault (1995). This study provides presumption that inflation is a bad idea but this case is not decisive without supporting empirical findings. Shahbaz (2013) used data for the period 1971-2010 in Pakistan, using ARDL bounds testing approach to co-integration method and found there is a co-integration between inflation and economic growth. Malla (1997) also, used a small sample of eleven OECD countries in a pooled time series and cross-section fashion to 
examine the relationship between inflation and growth and found that negative effects of inflation on economic growth outweigh its positive effects.

Bittencourt (2012) examined the inflation-growth nexus from Latin America using panel time evidence and found negative effects of inflation on output. Attari and Javed (2013) and Smyth (1992) also confirmed the negative relationship between inflation and growth. With the inverse relationship between inflation and economic growth, Smyth (1992) estimated that in the USA, a one percentage point increase in inflation reduces the country's annual growth rate by $0.223 \%$. Vinaygathasan (2013) also investigated the possible relationship between inflation and economic growth using dynamic panel threshold analysis for Asian economics and found inflation to only have an inverse effect on economic growth only if it exceeds a threshold of approximately 5.43, but has no effect on growth if it the rate of inflation is below the threshold level.

Recent studies on the relationship between inflation and economic growth reveals a non-linear relationship or non-existent below some critical level and affect the economy when the level is exceeded. Eggoh and Khan (2014) and Seleteng et al. (2013) were among authors to identify the possibility of such a non-linear relationship. They argued that inflation helps economic growth when it is below a threshold value, but has a negative influence if it is above that threshold level. Mireku (2012) using Bank of Ghana data calculated a threshold level of $9 \%$ for Ghana. In a similar study in Ghana, Frimpong and Oteng-Abayie (2010) also estimated a threshold level of $11 \%$ for Ghana in the year 2010. This disparity in the estimated threshold for Ghana may be due to difference in their methodology and the time frame of their studies. Also, examining the non-linear relationship between inflation and economic growth, Burdekin (2000) showed that the effects of inflation on growth reverses substantially as the inflation rate rises. He concluded that the threshold at which inflation first begins to negatively affect growth is around eight percent for industrial economies and three percent or less for developing countries.

In the case of the Ghanaian economy, Kinful (2005) explained how inflation has been a persistent problem. Thus the average inflation rate jumped from about $5.5 \%$ over the period 1960-1970 to $58 \%$ over the period 1971-1983. This trend was attributed to economic policies before Structural Adjustment Programme (SAP), which were mainly severe regulation of prices for consumer goods and services that resulted in shortage of goods and decline in many services. The rate of inflation has remained volatile and had been one of the areas where success has not been very significant after the implementation of the Structural Adjustment Programme (Aryeetey, Fosu \& Bawumia, 2001). The average inflation recorded between 2000 to 2005 and 2006 to 2010 was 21.10 percent and 13.63 percent respectively.

Ghana's economic growth performance as in most developing countries has been inconsistent and failed to achieve its set targets over the years. While GDP was expected to grow by about eight percent to achieve the Millennium Development Goals; actual 
growth has averaged around five percent since 1990 (World Bank, 2013). The question that remained unanswered is, is this inconsistency in economic performance due to the rate of inflation? Most empirical results are mixed on the causes of the fluctuation in the performance of the economy Mireku (2012). Also, since the 1970 s to 2012, the average level of inflation in Ghana is above 13 percent. Using the threshold calculated by Mireku (2012) and Frimpong and Oteng-Abayie (2010), this study aims to find the actual nexus between inflation and growth in the case of Ghana during the period 1986 to 2012 as this period marks the full implementation of economic reforms to date. This paper adopts the cointegration and the error correction model with inclusion of other control variables such as money supply, labour force, gross fixed capital formation, government expenditure and interest rate. The rest of the paper is structured as follows: Section two presents the theoretical model specification. Section three presents empirical model specification and data source. Section four presents and discusses the empirical results. And finally, section five presents the conclusion of the study.

Ghana's economic growth performance as in most developing countries has been inconsistent and failed to achieve its set targets over the years. While GDP was expected to grow by about 8 percent to achieve the Millennium Development Goals; actual growth has averaged around five percent since 1990 (World Bank, 2013). The question that remained unanswered is, is this inconsistency in economic performance due to the rate of inflation? Most empirical results are mixed on the causes of the fluctuation in the performance of the economy. Also, since the 1970s to 2012, the average level of inflation in Ghana is above 13 percent. Using the threshold calculated by Mireku (2012) and Frimpong and OtengAbayie (2010), this study aims to find the actual nexus between inflation and growth in the case of Ghana during the period 1986 to 2012. This paper adopts the co-integration and the error correction model with inclusion of other control variables such as money supply, labour force, gross fixed capital formation, government expenditure and interest rate. The rest of the paper is structured as follows: Section two presents the theoretical model specification. Section three presents empirical model specification and data source. Section four presents and discusses the empirical results. And finally, section five supplies some concluding comments.

\section{Methodology}

\section{Theoretical Model Specification}

The usual neo-classical model of Solow (1956) explains economics as resulting from the combination of two elements, namely capital (K) and labour (L) as shown below:

$$
Y=f(K, L)
$$

Where $\mathrm{Y}$ in this equation is defined as growth. From the above equation, Solow assumes that this production function exhibits constant returns to scale (CRS), which implies that 
if all inputs are increased by a certain multiple, output will increase by exactly that same multiple. Thus for any positive constant I the following condition must hold:

| $Y=f(|K| L$,

Assuming that I is $1 / \mathrm{L}$ then equation 1 becomes:

$\frac{Y}{L}=f\left(\frac{K}{L}, \frac{L}{L}\right)=f\left(\frac{K}{L}, 1\right)$

This shows the output per unit of labour, therefore putting equation (3) into equation (2), we have

$y=f(k)$

Where $y$ and $\mathrm{k}$ are defined as $\mathrm{Y} / \mathrm{L}$ and $\mathrm{K} / \mathrm{L}$ respectively.

In addition to assuming constant returns to scale, Solow further assumed positive but diminishing marginal returns to any single inputs. That is the slope of output continuously decreases because each additional increase in $K$ relative to $L$ causes smaller and smaller output (Van den Berg, 2001). This is the inherent characteristics of the Solow model that brings convergence to light.

The model assumes that a constant fraction of output d, is invested, that is, $S=\mathrm{d} Y$. Further assuming the existing capital depreciates at rate $r$ the competitive equilibrium of the Solow model can be written as:

$$
k_{t+1} \square k_{t}=\frac{1}{1+n}\left[\mathrm{~d} f\left(k_{t}\right) \square(\mathrm{r}+n) k_{t}\right]
$$

Where $n$ is defined as growth rate.

The left hand-side of equation (5) states that the change in capital stock per unit of labour, is determined by two terms on the right-hand side of the equation, where the first term $\mathrm{d} f\left(k_{t}\right)$, is the actual investment per unit of labour, and the second term $(r+n) k_{t}$, is called break-even investment, the amount of capital stock must be invested to keep the capital per unit of labour at its existing level. In the steady state, equation (5) can be rewritten as:

$$
k_{t+1}=k_{t} \square \mathrm{d} f\left(k_{t}\right)=(\mathrm{r}+n) k_{t}
$$

When the actual investment per unit of labour exceeds the breakeven investment, $k_{t+1} \square k_{t}>0, k$ increases until it reach the steady state level, and vice versa. Eventually, $k$ will converge to its steady state level regardless of where it starts (Romer, 1994). In the long run, when the economy converges to its steady state level of capital stock per unit 
of labour, real output grows at the same rate as population growth rate $n$. Given the assumption of constant growth rates of savings, population growth rate, and the constant return to scale (CRS), Solow's growth model states that growths in key macro-economic variables are determined by the population growth rate.

However, the question one needs to ask is how much of the output growth can be attributed to other factors other than capital and labour. It is as a result of this that Solow (1956) decomposes the growth in output into three components; via physical capital accumulation, labour force growth, and total factor productivity (TFP) growth - with each identified as contributing to production. The TFP growth is considered as the effect of exogenous technological progress, which can also be reflected in increasing productive efficiency. To account for this, Solow used the Cobb-Douglas production function and started from this simple growth equation which is stated as:

$Y_{t}=f(K, L, A)$

Where: $Y_{t}$ is economic growth at time $\mathrm{t}, \mathrm{A}=$ total factor productivity L=labour stock, $\mathrm{K}=$ capital stock. Applying the Cobb-Douglas production function, Solow stated the equation as

$$
Y_{t}=A K^{\mathrm{a}} L^{\mathrm{b}}
$$

From this, Solow defined his TFP to be technology. According to Solow it is convenient to use the Cobb-Douglas production function because it exhibits constant returns to scale. The key point to note here is that the variable $\mathrm{A}$ is not constant but varies with different production functions as used in literature including Fosu and Magnus, (2006). Aside the traditional input of production-labour and capital, the model assumes other conventional inputs.

\section{Empirical Model Specification}

Following the work of Sakyi (2011), Fosu and Magnus (2006) and Mansouri (2005) the empirical model used for this study is specified as follows:

$$
\begin{aligned}
& Y_{t}=A_{t} K_{t}^{\mathrm{a}} L_{t}^{\mathrm{d}} \\
& A_{t}=f\left(G E X P_{t}, I N T_{t}, M 2{ }_{t} C P I_{t}\right)=G E X P_{t}^{\mathrm{b}_{1}} I N T_{t}^{\mathrm{b}_{2}} M 2_{t}^{\mathrm{b}_{3}} C P I_{t}^{\mathrm{b}_{4}}
\end{aligned}
$$

Substituting equation (10) into equation (9) gives:

$$
Y_{t}=\mathrm{h} K_{t}^{\mathrm{a}} L_{t}^{\mathrm{d}} G E X P_{t}^{\mathrm{b}_{1}} I N T_{t}^{\mathrm{b}_{2}} M 2_{t}^{\mathrm{b}_{3}} C P I_{t}^{\mathrm{b}_{4}} \ell^{\mathrm{e}_{t}}
$$

For the purpose of linearity, we apply logarithm to equation 11 with the exception of interest rate which gives: 


$$
\begin{aligned}
\ln Y_{t} & =\operatorname{lnh}+\mathrm{b}_{1} \ln G E X P_{t}+\mathrm{b}_{2} I N T_{t}+\mathrm{b}_{3} \ln M 2_{t}+\mathrm{b}_{4} \ln C P I_{t} \\
& +\mathrm{a} \ln K_{t}+\mathrm{d} \ln L_{t}+\mathrm{e}_{t} \ln \ell \ldots \ldots \ldots \ldots \ldots \ldots \ldots \ldots \ldots \ldots \ldots \ldots \ldots \ldots \ldots \ldots
\end{aligned}
$$

Let $\operatorname{lnh}=\mathrm{b}_{0}$ and $\ln \ell=1$, equation 12 can be written as:

$$
\begin{aligned}
\ln Y_{t} & =\mathrm{b}_{0}+\mathrm{b}_{1} \ln G E X P_{t}+\mathrm{b}_{2} I N T_{t}+\mathrm{b}_{3} \ln M 2_{t}+\mathrm{b}_{4} \ln C P I_{t} \\
& +\mathrm{a} \ln K_{t}+\mathrm{d} \ln L_{t}+\mathrm{e}_{t} \ldots \ldots \ldots \ldots \ldots \ldots \ldots . . .(13)
\end{aligned}
$$

As a result, the long run growth model to be estimated in this study is:

$$
\begin{aligned}
\ln Y_{t} & =\mathrm{b}_{0}+\mathrm{b}_{1} \ln G E X P_{t}+\mathrm{b}_{2} I N T_{t}+\mathrm{b}_{3} \ln M 2_{t}+\mathrm{b}_{4} \ln C P I_{t} \\
& +\mathrm{a} \ln K_{t}+\mathrm{d} \ln L_{t}+\mathrm{e}_{t} \ldots \ldots \ldots \ldots \ldots \ldots \ldots \ldots . . .(14)
\end{aligned}
$$

From (14), the growth level $\square \ln Y_{t}$ to be estimated also depends on previous year growth $\square \ln Y_{t \square i}$, and the lagged values of the other explanatory variables. Therefore the short run model to be estimated is specified as equation (15) and j, k, p, q, w, g, n and h assume an infinity value as $i=1 \sim \infty$ for all values of $j, k, p, q, w, g, n$ and $h$.

$$
\begin{aligned}
\square \ln Y_{t}=\mathrm{a}_{0} & +\square_{i=1}^{j} \mathrm{q} \square \ln Y_{t \square i}+\square_{i=1}^{k} \mathrm{~b}_{1} \square \ln G E X P_{t \square i}+\prod_{i=1}^{p} \mathrm{~b}_{2} \square I N T_{t \square i}+\prod_{i=1}^{q} \mathrm{~b}_{3} \square \ln M 2_{t \square i} \\
& +\square_{i=1}^{w} \mathrm{~b}_{4} \square \ln C P I_{t \square i}+\square_{i=1}^{n} \mathrm{a} \square \ln K_{t \square i}+\square_{i=1}^{h} \mathrm{~d} \square \ln L_{t \square i}+\mathrm{j} E C T_{t \square \square}+\mathrm{m} \ldots \ldots . . .
\end{aligned}
$$

Where $Y_{t}, K_{t}$ and $\mathrm{L}_{t}$ are already defined, $G E X P_{t}$ is government expenditure, $I N T_{t}$ is interest rate proxy by prime rate, $M 2_{t}$ is money supply, $C P I_{t}$ is Consumer Price Index a proxy for inflation, $\mathrm{ln}$ is the natural logarithmic operator, $\square$ is difference operator and $E C T_{t \square 1}$ is error correction term lagged one period. The coefficients $\mathrm{b}_{1}$ to $\mathrm{b}_{4}, \mathrm{a}$ and $\mathrm{d}$ are the elasticities of the respective variables, with $\mathbf{j}$ showing the speed of adjustment, $\mathrm{b}_{0}$ is the drift component, $t$ denotes time ande and $\mathrm{m}$ are the stochastic error terms.

The expected signs for the various coefficients are: $\beta_{1}, \beta_{3}, \alpha>0$. This indicates that the economic growth is directly related to these explanatory variables and also $\beta_{2}, \beta_{4}<0$ indicate an inverse relationship among these explanatory variables.

\section{Data Type and Sources}

The study employed secondary data. Quarterly time series data were generated from the annual time series collected from 1986 to 2012, using Gandolfo (1981) algorithm. The series were drawn from World Development Indicators (World Bank, 2013) and Bank of Ghana data base. 


\section{Results and Discussion}

In order to examine the link between inflation and economic growth, it is imperative to carry out unit root test and Co - integration test.

Table 1: Unit root test: ADF test for the order of integration

\begin{tabular}{llllllr}
\hline Levels & \multicolumn{2}{l}{ (Trend and Intercept) } & & \multicolumn{2}{l}{$\mathbf{1}^{\text {st }}$ Difference (Trend and Intercept) } \\
\hline Variables & ADF Statistic & Lag & variable & ADF Statistic & Lag & IO \\
\hline LM2 & $-1.898325(0.3319)$ & 0 & DLM2 & $-6.049500(0.0000)^{* * *}$ & 0 & $I(1)$ \\
\hline LCPI & $0.975420(0.9999)$ & 0 & DLCPI & $-6.020188(0.0000)^{* * *}$ & 0 & $I(1)$ \\
\hline LGEXP & $-1.849343(0.3549)$ & 1 & DLGEXP & $-4.426321(0.0032)^{* * *}$ & 0 & $I(1)$ \\
\hline LGFCF & $-2.380250(0.3875)$ & 1 & DLGFCP & $-5.772820(0.0000)^{* * *}$ & 3 & $I(1)$ \\
\hline INT & $-1.602139(0.7850)$ & 4 & DINT & $-7.348021(0.0000)^{* * *}$ & 3 & $I(1)$ \\
\hline LLF & $-2.050154(0.5663)$ & 4 & DLLF & $-15.23682(0.0000)^{* * *}$ & 2 & $I(1)$ \\
\hline LRGDP & $2.900595(1.0000)$ & 5 & DLRGDP & $13.72518(0.0000)^{* * *}$ & 2 & $I(1)$ \\
\hline
\end{tabular}

Note: $\mathrm{D}$ denotes first difference. ${ }^{* * *}$ and ${ }^{* *}$ represent significance at the $1 \%$ and $5 \%$ levels respectively. Numbers in brackets are P-Values. OI represents the order of integration.

Table 2: Unit root test: PP test for the order of integration

\begin{tabular}{lllllll} 
Levels & \multicolumn{1}{l}{ (Trend and Intercept) } & & \multicolumn{2}{l}{$\mathbf{1}^{\text {st }}$ Difference (Trend and Intercept } \\
\hline Variables & PP Statistic & Bwd & variable & PP Statistic & Bwd & $I O$ \\
\hline LM2 & $-0.801708(0.9614)$ & 8 & DLM2 & $-7.714534(0.0000)^{* * *}$ & 10 & $I(1)$ \\
\hline LCPI & $0.649827(0.9995)$ & 4 & DLCPI & $-5.855388(0.0000)^{* * *}$ & 5 & $I(1)$ \\
\hline LGEXP & $-0.617320(0.9756)$ & 3 & DLGEXP & $-4.255870(0.0054)^{* * *}$ & 1 & $I(1)$ \\
\hline LGFCF & $-2.072856(0.5541)$ & 2 & DLGFCP & $-5.883607(0.0000)^{* * *}$ & 6 & $I(1)$ \\
\hline INT & $-1.992939(0.5977)$ & 1 & DINT & $-6.903012(0.0000)^{* * *}$ & 2 & $I(1)$ \\
\hline LLF & $0.427052(0.9990)$ & 11 & DLLF & $-3.028713(0.0354)^{* *}$ & 9 & $I(1)$ \\
\hline LRGDP & $-1.201507(0.90440$ & 15 & DLRGDP & $-6.268485(0.0000)^{* * *}$ & 9 & $I(1)$ \\
\hline
\end{tabular}

Note: D denotes first difference. ${ }^{* * *},{ }^{* *}$ and ${ }^{*}$ represent significance at the $1 \%, 5 \%$ and $10 \%$ levels respectively. Numbers in brackets are P-Values. OI represents the order of integration. Bwd represents bandwidth. 


\section{Co - integration Test}

Contributing to the significance and rational for cointegration analysis, Johansen (1991) argued that cointegration can be used to establish whether there exists a linear long-term economic relationship among variables of interest. Pesaran and Shin (1995) added that cointegration enable researchers to determine whether there disequilibrium in various markets. In this regard, Johansen (1991) asserts that cointegration allows us to specify a process of dynamic adjustment among the cointegrated variables and in disequilibrated markets. Given that the series are $I$ (1), the cointegration of the series is a necessary condition for the existence of a long run relationship. Under the assumption of linear trend in the data, and an intercept and trend in the co-integration equation the results of the Johansen cointegration test are presented in the table below:

Table 3: Johansen's co-integration test (trace) results for real GDP model

\begin{tabular}{|c|c|c|c|c|}
\hline Hypothesized & & Trace & 0.05 & \\
\hline No. of $C E(s)$ & Eigenvalue & Statistic & Critical Value & Prob.** \\
\hline None ${ }^{* *}$ & 0.371933 & 168.9256 & 150.5585 & 0.0030 \\
\hline At most $1^{* *}$ & 0.307018 & 124.2752 & 117.7082 & 0.0179 \\
\hline At most $2^{* *}$ & 0.239275 & 89.06711 & 88.80380 & 0.0479 \\
\hline At most 3 & 0.225571 & 62.81270 & 63.87610 & 0.0612 \\
\hline At most 4 & 0.181450 & 38.27232 & 42.91525 & 0.1350 \\
\hline At most 5 & 0.141013 & 19.05116 & 25.87211 & 0.2778 \\
\hline At most 6 & 0.045386 & 4.458994 & 12.51798 & 0.6751 \\
\hline
\end{tabular}

Trace test indicates 3 co-integrating equation(s) at both $5 \%$ and $1 \%$ levels. Note: $\left.{ }^{*}{ }^{* *}\right)$ denotes rejection of the hypothesis at the $5 \%(1 \%)$ level

It can be observed from Table 3 that the trace statistic indicates the presence of cointegration among the variables. Specifically, the null hypothesis of no co-integrating relationship or vector $(r=0)$ is rejected since the computed values of the trace statistic of 89.06711 is greater than its critical value of 88.80380 at $5 \%$. That is, applying the Johansen test to the quarterly series spanning from 1986:Q1 to 2012:Q4 enable us to conclude that there exits at most three co-integrating relationships. But for the purpose of this study, the first co-integration relationship will be estimated. This confirms the existence of a stable long-run relationship among price level, real GDP, money supply, interest rate, government expenditure labour force and gross fixed capital formation. Based on the fact that there are co-integrating vectors among the variables, the estimated long-run equilibrium relationship for real GDP was derived from the unnormalised vectors. 


\section{Long-Run and Short-Run Dynamics of Real GDP}

The result presented in Table 4 describe the descriptive statistics of the variables use in the study.

Table 4: Descriptive statistics of the study

\begin{tabular}{llllllll}
\hline & LCPI & LGEXP & LGFCF & LLF & LM2 & LRGDP & INT \\
\hline Mean & 1.693602 & 17.65644 & 1.556135 & 2.905793 & 18.36339 & 21.89595 & 26.43250 \\
\hline Median & 1.955570 & 17.62558 & 1.648171 & 2.912349 & 18.40414 & 21.87690 & 26.00000 \\
\hline Maximum & 4.069942 & 21.03069 & 2.015911 & 3.142016 & 22.16461 & 22.73766 & 45.00000 \\
\hline Minimum & 1.203203 & 14.08524 & 0.820686 & 2.518447 & 14.26898 & 21.34464 & 12.50000 \\
\hline Std. Dev. & 1.546158 & 2.058956 & 0.316130 & 0.051859 & 2.287575 & 0.339522 & 9.591061 \\
\hline Skewness & -0.278389 & -0.043189 & -0.829571 & -3.009324 & -0.113443 & 0.265965 & 0.584254 \\
\hline Kurtosis & 1.753260 & 1.845555 & 2.720786 & 37.00373 & 1.798526 & 2.197901 & 2.466077 \\
\hline Jarque-Bera & 7.768173 & 5.584188 & 11.79464 & 4968.656 & 6.229242 & 3.859633 & 6.877018 \\
\hline Probability & 0.07720 & 0.061293 & 0.17960 & 0.17290 & 0.074500 & 0.145175 & 0.1058 \\
\hline Sum & 169.3602 & 1765.644 & 155.6135 & 290.5793 & 1836.339 & 2189.595 & 2643.250 \\
\hline Sum Sq. Dev. & 236.6697 & 419.6906 & 9.893891 & 0.266245 & 518.0670 & 11.41223 & 9106.857 \\
\hline Observations & 108 & 108 & 108 & 108 & 108 & 108 & 108 \\
\hline
\end{tabular}

Source: Author's estimation, 2013

The result shown in Table 4 indicates that all the variables have positive average values (means). The minimal deviation of the variables from their means with the exception of the interest rate as shown by the standard deviations attests to the fact that taking logs of variables minimizes their variances. The standard deviation of interest rate is relatively big because it was not logged. In addition, the result in Table 4 again reveals that almost all the variables show signs of negative skeweness with the exception of real GDP and interest rate. The Jarque-Bera statistic also shows that the null hypothesis that the series are drawn randomly from normally distributed populations cannot be rejected for most of the variables.

The result from the long run and short run relationship of real GDP is presented in Table 5 and 6 respectively. 
Table 5: Long-run estimates: Dependent variable is LRGDP

\begin{tabular}{llll}
\hline Variable & Coefficient & Standard Error & T-Ratio (Prob.) \\
\hline $\mathrm{T}$ & 0.005211 & 0.0021121 & $2.467(0.031)^{* *}$ \\
\hline LGEXP & 0.133752 & 0.06421 & $2.083(0.063)^{*}$ \\
\hline LCPI & -0.18915 & 0.0394 & $4.801(0.008)^{* * *}$ \\
\hline LGFCF & 0.09067 & 0.04118 & $2.202(0.042)^{* *}$ \\
\hline LLF & 3.10438 & 0.61579 & $5.041(0.006)^{* * *}$ \\
\hline LM2 & 0.15795 & 0.0813 & $1.956(0.077)^{*}$ \\
\hline INT & -0.002302 & 0.0011 & $-2.093(0.066)^{*}$ \\
\hline
\end{tabular}

Table 6: Error Correction Model (ECM) for real GDP model

\begin{tabular}{lllll}
\hline Variable & Coefficient & Std. Error & t-Statistic & Prob. \\
\hline ECT(-1) & -0.182461 & 0.052016 & -3.507786 & 0.0007 \\
\hline $\mathrm{D}($ LRGDP(-1)) & 0.582650 & 0.158911 & 3.666510 & 0.0004 \\
\hline $\mathrm{D}(\mathrm{LRGDP}(-2))$ & 1.218403 & 0.160966 & 7.569329 & 0.0000 \\
\hline $\mathrm{D}(\mathrm{LRGDP}(-4))$ & 1.392943 & 0.560333 & 2.485919 & 0.0150 \\
\hline $\mathrm{D}(\mathrm{LCPI}(-2))$ & -0.010157 & 0.005673 & -1.790581 & 0.0779 \\
\hline $\mathrm{D}(\mathrm{LGEXP}(-4))$ & 0.090593 & 0.040398 & 2.242494 & 0.0283 \\
\hline $\mathrm{D}(\mathrm{LLF}(-3))$ & 2.858470 & 0.221586 & 12.90006 & 0.0000 \\
\hline $\mathrm{D}(\mathrm{LGFCF}(-1))$ & 0.045897 & 0.021678 & 2.117184 & 0.0361 \\
\hline $\mathrm{D}(\mathrm{LM} 2(-3))$ & 0.071469 & 0.029593 & 2.415105 & 0.0178 \\
\hline $\mathrm{C}$ & 0.082254 & 0.015533 & 5.295414 & 0.0000 \\
\hline
\end{tabular}

R-squared $=0.768533$ DW $=2.139228$ F-statistic $=22.41178$ Prob $=0.000000$

The result in Table 5 indicates that, holding all other factors constant, as time passes by, real GDP in Ghana will grow by approximately $0.521 \%$ each quarter. This means that time has a positive impact on real GDP. This is justified by the fact that as time passes by technology, institutions and human behaviour change and such changes will naturally grow the activities in the real sector.

The long run and the short run results presented in Table 5 and 6 shows that the Consumer Price Index as a proxy for inflation has a significant impact on economic growth with coefficients of -0.1892 and -0.010 respectively. This shows that increases in 
economic growth leads to lower inflation. Once the economy grows, it implies an increase in the incomes of workers in general, which gives them additional purchasing power. This additional income leads to excess demand which in the end exerts an upward pressure on price levels in the economy. The finding is in conformity with the work of Mallik and Chowdhury (2001), who look at the relationship between inflation and GDP growth for four South Asian countries (Bangladesh, India, Pakistan, and Sri Lanka) and found evidence of a long-run negative relationship between GDP growth rate and inflation for all four countries. Stockman (1981) argued that individual's welfare falls whenever there is an increase in inflation. The negative effect of inflation on economic growth is an indication that inflation causes economic growth to decline in the long-run, which is also consistent with the results by Bittencourt (2010) who studied the effects of inflation for four Latin American Countries (Argentina, Bolivia, Brazil and Peru) and found that inflation has a negative and significant effect on economic growth. The inverse relationship between inflation and economic growth is also confirmed by the studies of Ahmed and Mortaza (2005) and Gokal and Hanif (2004).The results, however, contradict the findings by Erbaykal and Okuyan (2008) and Chimobi (2010). Erbaykal and Okuyan (2008) showed no statistically significant long-run relationship between inflation and economic growth for Turkey. Chimobi (2010) found no co-integrating relationship between inflation and economic growth for Nigeria, implying no long-run relationship between the two variables. Also, Mallik and Chowdhury (2001) found a positive relationship between inflation and economic growth for four South Asian Countries (Bangladesh, India, Pakistan and Sri Lanka).

Gross capital formation, as a proxy for capital with a coefficient of 0.0907 in the long run and 0.046 in the short run indicate that a one percent increase in capital input would result in approximately 0.091 and 0.046 percent increase in real GDP, holding all other factors constant. The sign of the capital variable support the theoretical conclusion that capital contributes positively to growth of GDP since the coefficient of capital in both the long and the short run growth equation is positive and significant. This positive relationship between capital stock and economic growth is consistent with the expectation of the classical economic theory. This relationship is in conformity with the supply leading view of the relationship between financial development and economic growth in accordance with the prediction by the McKinnon - Shaw hypothesis. It is also in conformity with the finding of Kiran et al. (2009), and Odhiambo (2008), but contradicts the findings of Quartey and Prah (2008) for Ghana and Ahmed (2008) for Sierra Leone.

The results in Table 5 and 6 again shows that the coefficient of labour force in both the long and the short run is expected to be positive. This means that an increase in labour force of the country contributes positively to the development of the country. This therefore indicates that labour force is a key channel through which real GDP can increase. This is still consistent with the argument of (Jayaraman \& Singh, 2007) who asserted that there can be no growth achievement without the involvement of labour as a factor input hence, the positive and significant coefficient. This result, however, contradicts the work of Asiedu (2010) who found a negative effect of labour force on economic growth. This 
commensurates with the fact that the public sector remains the single most important source of employment for job seekers in Africa, in general, and Ghana, in particular (World Bank, 2008. While this situation is not particular to Africa or Ghana, nonetheless, the poor development of the private sectors forces the government to absorb job seekers, sometimes for political reasons, thereby causing a diminishing return to labour.

Both results from the long and the short run on government expenditure which served as an exogenous variable was statistically significant and it exerted a positive impact on economic growth. This means that when government increases its expenditure, especially in the area of infrastructure development, it exerts positive effect on growth. This is because availability of developed infrastructure such as roads, hospitals, and industries help to boost the productivity capacity of countries and in the finally analysis increase the country's economic growth. The finding from this study is also in conformity with the findings by Kouassy (1994) for Ivory Coast and Saidu (2010) for Sierra Leone.

The results in Table 5 and 6, indicate that money supply (LM2) has a positive effect on real GDP. A one percent increase in money supply will increase real GDP by approximately o.158 percent. This effect is in line with the Monetarist view that money supply multiplier is directly proportional to output in real terms. This finding is consistent with the findings of Bhattarai (2014), Miao and Xie (2013) and Schabert (2009) who also studied the relationship between money and economic growth in various countries.

Besides, the results from both the long and the short run as shown in Table 5 and 6 indicates that interest rate has a negative effect on real GDP with a coefficient of 0.002302 . This means that a one percent increase in interest rate will cause real GDP to decrease by approximately 0.0023 percent in the long run. Thus this negative effect of interest rate on real GDP conforms to the Keynesian view that low interest rate serves as an incentive to invest by spending more and saving less whilst high interest rates deters investment. Therefore, when financial institution charge high interest rate on loans to the private sector, it will lead to a higher cost of production for them and this would force them to cut down their levels of productivity, which could have a negative effect on the growth of the economy. This result is in conformity with Huang and Chang (2010).

The results from the vector error correction model as displayed in Table 6 suggest that the ultimate effect of previous periods' values of real GDP on current values of real GDP in the short-run is positive and significant at lag one (1), two (2) and four (4). The implication is that current values of real GDP are affected by previous quarters' values of real GDP. The coefficient of the lagged error-correction term is negative and statistically significant as expected at $1 \%$ significance level, suggesting that it would take a short time for the system to return to its equilibrium once it is out of equilibrium. Thus Bannerjee, Dolado and Mestre (1998) asserted that a highly significant error correction term further confirms the existence of a stable long-run relationship. From the results in the table the estimated coefficient of the error correction term is -0.182461 which implies that the speed of adjustment is approximately $18.25 \%$ per quarter or $73 \%$ per year. This negative 
and significant coefficient is an indication that co-integrating relationship exists among real GDP and its explanatory variables. The size of the coefficient of the lagged error correction term (ECT-1) denotes that about $18.25 \%$ of the disequilibrium in the output market caused by previous years' shocks converges back to the long-run equilibrium in the current year. Thus, the study shows that the variables in the model show evidence of moderate response to equilibrium when shocked in the short-run. The rule of thumb, however, is that the larger the error correction coefficient (in absolute term), the faster the variables equilibrate in the long-run when shocked (Acheampong, 2007). However, the magnitude of the coefficient in this study suggests that the speed of adjustment to the long-run changes is relatively high.

\section{Granger Causality Test}

To verify the direction of causality among the variables, the pairwise Granger causality test was conducted and the result shown in Table 7

Table 7: Granger causality results for real GDP Model

\begin{tabular}{lll}
\hline Null Hypothesis: & F-Statistic & Prob. \\
\hline LRGDP does not Granger Cause LCPI & 5.52254 & $0.0054^{* * *}$ \\
\hline LCPI does not Granger Cause LRGDP & 5.13155 & $0.0077^{* * *}$ \\
\hline LRGDP does not Granger Cause LGEXP & 9.60403 & $0.0002^{* * *}$ \\
\hline LGEXP does not Granger Cause LRGDP & 14.1220 & 4. E-o6 \\
\hline LRGDP does not Granger Cause LLF & 15.5647 & 1. E-o6 \\
\hline LLF* does not Granger Cause LRGDP & 36.1724 & $2 . E-12^{* * *}$ \\
\hline LRGDP does not Granger Cause LM2 & 5.63452 & $0.0049^{* * *}$ \\
\hline LM2 does not Granger Cause LRGDP & 9.12388 & $0.0002^{* * *}$ \\
\hline INT does not Granger Cause LRGDP & 7.61091 & $0.0009^{* * *}$ \\
\hline LRGDP does not Granger Cause INT & 1.81082 & $0.1692^{* *}$ \\
\hline LRGDP does not Granger Cause LGFCF & 10.8870 & $6 . E-05^{* * *}$ \\
\hline LGFCF does not Granger Cause LRGDP & 13.9588 & $5 . E-06^{* * *}$ \\
\hline
\end{tabular}

${ }^{* * *} \mathrm{p}<0.01,{ }^{* *} \mathrm{p}<0.05,{ }^{*} \mathrm{p}<0.1$

The Granger causality test results in the Table 7 suggest that the null hypothesis that inflation does not Granger cause real GDP is rejected, implying inflation does Granger cause real GDP. Also, the results rejected the null hypothesis that real GDP does not granger cause inflation. This means that real GDP predicts inflation and inflation as well 
predicts real GDP. From the results it is clear that there is a bi-directional causality running from inflation to real GDP and from real GDP to inflation in Ghana.

Also, from the Table 7, there is a bi-directional causality running from real GDP to government expenditure and from government expenditure to real GDP since the null hypothesis that real GDP does not Granger cause government and that government expenditure does not Granger cause real GDP are both rejected at 1\% significance level. There is a bi-directional causality running from real GDP to labour force and vice versa since the null hypothesis that, real GDP does not Granger cause labour force and that labour force does not Granger cause real GDP are both rejected at 1\% significance level.

Again, the null hypothesis that money supply does not Granger cause real GDP and that real GDP does not Granger cause money supply are both rejected at 1\% significance level, implying that there is a bi-directional causality running from money supply to real GDP and vice versa. Also, in the results of Table 7 , there is a uni-directional causality running from interest rate to real GDP since the null hypothesis that, interest rate does not Granger cause real GDP is rejected at 1\% significance level. Thus the null hypothesis that, real GDP does not Granger cause interest rate failed to be rejected implying that, real GDP really does not Granger cause interest rate.

Finally, the null hypothesis that capital does not Granger cause real GDP and that real GDP does not Granger cause capital are both rejected at 1\% significance level implying that, there is a bi-directional causality running from capital to real GDP and from real GDP to capital.

\section{Conclusion}

This paper examine the link between inflation and economic growth in Ghana, using data from World development indicators (2014) and Bank of Ghana. The empirical result from the study reveal a negative relationship between inflation and economic growth. This finding is consistent with other findings in the literature including Bittencourt (2010), Ahmed and Mortaza (2005) and Gokal and Hanif (2004). The interest rate was also found to have a negative influence on growth. However, capital formation, government expenditure, labour force and money supply all had positive impact on real GDP with the greatest impact resulting from labour force both in long - run and short - run. The correction term of the real GDP model shows that capital formation, labour force, government expenditure, money supply and interest rate can be used as policy variables to bring back real GDP to equilibrium in the face of short - run deviations

To boost economic growth in Ghana, the study recommends inflation targeting as the best monetary policy measures to boost economic growth. There is the need for government to increase its expenditure in the area of infrastructure development to increase output. Policies should be designed by government to increase investment in human capital by establishing more institutions to produce quality labour force in order to 
enhance economic growth. This in the long run will promote the level of economic growth in the country.

\section{References}

Acheampong, I. K. (2007). Testing McKinnon-Shaw thesis in the context of Ghana's financial sector liberalisation episode. International Journal of Management Research and Technology, 1(2), pp. 156-183.

Ahmed, A. D., (2008). Financial liberalization, financial development and growth in susaharan Africa's economic reform: An empirical investigation, Centre for Strategic Economic Studies, Victoria University, Australia.

Ahmed, S., \& Mortaza, G. (2005). Inflation and economic growth in Bangladesh. (Policy Analysis Unit Working Paper Series: WP 0604). Retrieved February 2010, from http://www.bangladesh-bank.org

Aryeetey, E., and Fosu A. K. (2005). Economic growth in Ghana: 1960-2000, Draft Chapter at African Economic Research Consortium (AERC) Growth Project Workshop, Cambridge.

Aryeetey, E., Fosu, A. and Bawumia, M. (2001). Explaining African growth performance: The case of Ghana. First draft paper prepared for the African Economic Research Consortium. Nairobi, Kenya.

Asiedu, M. (2010). Trade liberalization and economic growth in Ghana:1986-2007. Unpublished masters thesis, Kwame Nkrumah University of Science and Technology, Kumasi.

Attari I.J. and Javed (2013). Inflation, Economic Growth and Government Expenditure of Pakistan: 1980-2010. Procedia Economics and Finance, 5, 58-67.

Bannerjee, A., Dolado, J. and Mestre, R. (1998). Error-correction mechanism tests for cointegration in single equation framework. Journal of Time Series Analysis, 19, 26783 .

Barro, R. (2013). Inflation and economic growth.. Annals of Economics and Finanace, 14(1), 85-109.

Bhattarai Keshab (2014). Money and economic growth, The Journal of Economic Asymmetries, 11, pp. 8-18.

Bittencourt Manoel (2012). Inflation and economic growth in Latin America: Some panel time-series evidence. Economic Modelling, 29(2), 333-340.

Bittencourt, M. (2010). Inflation and economic growth in Latin America: Some panel time series evidence. (University of Pretoria Department of Economics Working Paper, 
Working Paper Series: 2010-11). Retrieved October 2011, Available at http://web. up.ac.za

Briault, Clive (1995). The Costs of Inflation.Bank of England Quarterly Bulletin, pp. 33-45.

Burdekin, R. C. K. (2000). When does Inflation Hurt Economic Growth? Different Nonlinearities for Different Economies. Working Papers in Economics, Claremont Colleges, August 2000.

Chimobi, O. P. (2010). Inflation and economic growth in Nigeria. Journal of Sustainable Development, 3(2), pp. 159-166.

Espinoza, R., Leon, H., Prasad, A., 2010, Estimating the Inflation-Growth Nexus -A smooth Transition Model, IMF Working Paper 10/76.

Eggoh Jude, C. and Khan M. (2014). On the nonlinear relationship between inflation and economic growth. Research in Economics, 68, pp. 133-143.

Erbaykal, E., and Okuyan, H. A. (2008). Does inflation depress economic growth? Evidence from Turkey. International Research Journal of Finance and Economics, 17, pp. 41-48.

Feder, G. (1983). On exports and economic growth. Journal of Development Economics, 12(1), pp. 59-73.

Frimpong, J. M. and Oteng-Abayie, E. F. (2010). When is Inflation Harmful? Estimating the Threshold Effect for Ghana. American Journal of Economics and Business Administration 2(3): pp. 232-239.

Fosu, O. E., and Magnus, F. J. (2006). Bounds testing approach to co-integration: An examination of foreign direct investment, trade and growth relationships. American Journal of Applied Sciences, 3(11), pp. 2079-2085.

Gandolfo, G. (1981). Qualitative analysis and econometric estimation of continuous time dynamic models. New York: North-Holland Publishing.

Gokal, M., and Hanif, S. (2004) Relationship between inflation and economic growth. (Economics Department Reserve Bank of Fiji, Working Paper 2004/o4). Retrieved November 2011, Available at http://www.reserve bank.gov

Jayaraman, T. K., and Singh, B. (2007). Foreign direct investment and employment creation in pacific island countries: An empirical study of Fiji. (ARTNET Working Paper No. 35/o7.) Asia-Pacific Research and Training Network on Trade. Retrieved January 25, 2012, from http://www.unescap.org

Jiranyakul, K. and Opiela, T. P. (2010). Inflation and inflation uncertainty in the ASEAN-5 economies. Journal of Asian Economics, 21(2). 
Johansen S. (1991). Estimation and hypothesis testing of contegration vectors in gaussian vector autoregressive models. Econometrica, 59(6), pp. 1551-1580.

Khan, M. and Senhadji, A. (2001).Threshold effects in the relationship between inflation and growth.IMF Staff Papers, 4821.http://ideas.repec.org/a/pal/imfstp/ v48y2oo1i1p1.html

Kiran, B, Yavus, N. C and Guris, B. (2009). Financial development and economic growth: A panel data analysis of emerging countries, International Research Journal of Finance and Economics, 30, pp. 1450-2887.

Kinful, E. (2005). Causal linkages among money, interest rate, price and output in Ghana: VECM Analysis. BOG. Working Paper, No. 05/11, Accra, July.

Kouassy, O. (1994). The IS/LM models and the assessment of the real impact of public spending on growth in Africa: Evidence from Cote d'Ivoire (pp. 63-78). In Atsain, A., Wangwe, S., \& Drabek, A. G. (Eds), Economic policy experience in Africa. What have we learned? African Economic Research Consortium. Nairobi, Kenya.

Malla, S. (1997). Inflation and economic growth: Evidence from a growth equation. (Department of Economics, University of Hawaii at Monoa, Maile Way, Honolulu, HI 96822, U.S.A, 1-13). Retrieved December 2011, available at http://www.economics.department.ca.

Mallik, G. and Chowdhury, A. (2001). Inflation and economic growth: Evidence from South Asian Countries. Asian Pacific Development Journal, 8(1), pp. 123-135.

Mansouri, B. (2005). The interactive impact of FDI and trade openness on economic growth: Evidence from Morocco. Paper presented at the 12th Economic Research Forum (ERF) Conference, Cairo.

Miao Jianjun and Xie Danyang (2013), Economic growth under money illusion, Journal of Economic Dynamics and Control, 37(1), pp. 84-103.

Mireku, P. B. (2012). Inflation and Growth: Estimation of Threshold Inflation Rate for Ghana. Bank of Ghana Working Paper.

Odhiambo, N. M. (2008). Financial depth, savings and economic growth in Kenya: A dynamic causal relationship. Economic Modelling, 25(4), pp. 704-713.

Pesaram M. H. and Smith R. (1995). Estimating long run relationships from dynamic heterogeneous panels. Journal of Econometrics, 68, 79-113.

Quartey P., and Prah, F., (2008), Financial Development and Economic Growth in Ghana: Is there a causal Link? African Finance Journal, Vol. 10 (1), pp. 28-54.

Romer, P. M. (1994). The origins of endogenous growth. Journal of Economic Perspectives. 8(1), pp. 3-22. 
Saidu, S. (2010) Inflation and economic growth in Sierra Leone. Unpublished master's thesis, University of Cape Coast, Cape Coast.

Sakyi, D. (2011). Trade openness, foreign aid and economic growth in post-liberalisation Ghana: An application of ARDL bounds test. Journal of Economics and International Finance, 3(3), pp. 146-156.

Schabert (2009). Money supply, macroeconomic stability, and the implementation of interest rate targets, Journal of Macroeconomics, 31(2), pp. 333-344.

Seleteng M, Bittencourt M. and Eyden Reneé van (2013). Non-linearities in inflationgrowth nexus in the SADC region: A panel smooth transition regression approach. Economic Modelling, 30, pp. 149-156.

Shahbaz Muhammad (2013). Linkages between inflation, growth and terrorism in Pakistan. Economic modelling, 32, pp. 496-506.

Solow, R. (1956). A contribution to the theory of economic growth. Quarterly Journal of Economics, 70, pp. 65-94.

Stockman, A. C. (1981). Anticipated inflation and the capital stock in a cash-in advance economy. Journal of Monetary Economics, 8, pp. 387-93.

Vinayagathasan Thanabalasingam (2013). Inflation and economic growth: A dynamic panel threshold analysis for Asian economies. Journal of Asian Economics, 26, pp. 3141.

World Bank (2013). World Development Report: Jobs, World Bank, Washington DC.

World Bank (2008). World Development Report: Agriculture for Development, World Bank, Washington DC.

Zulkhibri, M., and Majid A. (2007). Causality link between money, output and prices in Malaysia: An empirical re-examination. Applied Econometric and International Development. Euro-American association of economic development. Retrieved November 25, 2011, available at http://papers.ssrn. com/sol3/papers 